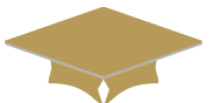

MEDRESEARCH

www.medresearch.in

\title{
Prevalence and determinants of overweight/obesity among affluent school children
}

\author{
S Kulkarni S. ${ }^{1 *}$, P Kumavat A. ${ }^{2}$, B Mane A. ${ }^{3}$ \\ DOI: https://doi.org/10.17511/ijphr.2016.i1.03 \\ 1* Shraddha S Kulkarni, Assistant Professor, Department of Community Medicine, Smt. Kashibai Navale Medical College, Pune, Maharastra, \\ India. \\ 2 Anjali P Kumavat, Professor, Department of Community Medicine, Dr V M Govt. Medical College, Solapur, Maharastra, India. \\ 3 Abhay B Mane, Professor, Department of Community Medicine, Smt. Kashibai Navale Medical College, Pune, Maharashtra, India.
}

Background \& Aim: Childhood obesity has a strong association with several non-communicable diseases. The longer the duration of obesity, higher is the risk. Hence, the present study was undertaken to study the prevalence and determinants of overweight/obesity among school children. Methods: The present cross-sectional study was carried out among school children studying in first to tenth standards during the school year 2011-12. From eleven private schools in the city, three schools were selected by simple random sampling. From each school 644, 551 and 495 students were selected by stratified random sampling. Pre-designed and pre-tested questionnaire was used for collection of data. Height and weight was measured and BMI was calculated. Overweight and obesity was assessed by BMI for age and sex [WHO criteria]. Results: Prevalence of overweight \& obesity was $14.97 \%$ and $7.10 \%$ respectively. The significant determinants of the overweight/ obesity were employed mothers, mixed diet, daily caloric intake > RDA, sleep at night< 8hour/day, television/video/computer time $\geq 2$ hour/day and physical activity < 1hour/day. Conclusion: Most of the determinants of obesity were related to lifestyle of the children. Hence, there is a need to educate the community about healthier eating habits, an active life style and protective role of breast feeding in preventing obesity for the health of future generation.

Keywords: Cross-sectional study, Obesity, Overweight, Prevalence, School Children

\section{Corresponding Author}

Shraddha S Kulkarni, Assistant Professor, Department of Community Medicine, Smt. Kashibai Navale Medical College, Pune, Maharastra, India. Email: drshraddha3008@gmail.com

\section{How to Cite this Article}

Kulkarni SS, Kumavat AP, Mane AB. Prevalence and determinants of overweight/obesity among affluent school children. Public Health Rev Int J Public Health Res. 2016;3(1):9-14.

Available From

https://publichealth.medresearch.in/index.php/ijphr/ article/view/24
To Browse

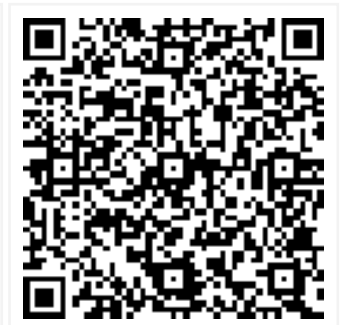

Manuscript Received 2016-01-07

Conflict of Interest No
Review Round 1 2016-01-15

Funding $\mathrm{Nil}$

Review Round 2
2016-01-24
Ethical Approval
Yes

Review Round 3

Accepted 2016-02-02

Plagiarism X-checker $6 \%$

(C) 2016 by Shraddha S Kulkarni, Anjali P Kumavat, Abhay B Mane and Published by Siddharth Health Research and Social Welfare Society. This is an Open Access article licensed under a Creative Commons Attribution 4.0 International License ttps://creativecommons.org/licenses/by/4.0/ unported [CC BY 4.0]. 


\section{Introduction}

The World Health Organization has described obesity as one of today's most neglected public health problems [1]. In many developing countries, obesity coexists with under-nutrition \& is more prevalent in urban than in rural populations [2]. India is following a trend of other developing countries that are steadily becoming more Obese [3].

Childhood obesity is a forerunner of obesity in adulthood which has a strong association with several non-communicable diseases [4]. Obesity is most likely to persist when its onset is in late childhood or adolescence \& the obesity is severe [2]. Importantly $60-85 \%$ of obese schoolchildren will remain obese as adults [3].

The effective prevention of adult obesity will require the prevention \& management of childhood obesity. Obesogenic lifestyle behaviours are less well developed in children and therefore more amenable to change. It is imperative to intervene early in childhood and adolescence to prevent and/or reverse the effects of overweight and poor eating habits [5]. The present study was undertaken to study the prevalence and determinants of overweight/obesity among children.

\section{Materials and Methods}

The present cross-sectional study was carried out among school children $6-15$ years of age studying in first to tenth standards during the school year 2011-12. School based data on obesity in India shows a prevalence of $5.6-24 \%$ among children and adolescents [6]. Considering the prevalence of obesity of $20 \%$, Allowable error $10 \%$ per cent and a non-response rate 10 per cent, the sample size was calculated as 1690 .

For selection of schools, a list of private schools in the city was obtained from the school authorities of the district education office. There were eleven private schools providing education from first to tenth standard with variable strength of students. Out of these three schools were selected by simple random sampling. From each school 644, 551 and 495 students were included in study both males and females studying in first to tenth standard in the age group of 6 to 15 years old by stratified random sampling.
Consent of school authorities was obtained after explaining objectives and methodology of study. The study was approved by the institutional ethical review committee and parental informed consent was obtained. Data were collected on regular working days from June 2011 to March 2012.

A predesigned, pretested questionnaire was handed over to each child and data on socio-demographic profile was obtained from their parents. Completed forms were collected on next day. A detailed questionnaire containing data regarding dietary habits, life-style, and physical activity was filled by interviewing students personally. Weight and Height of students were measured by adapting standard procedures. Weight was recorded in kilograms (to the nearest $0.5 \mathrm{~kg}$ ). The height was recorded in centimetres and then converted into meters for calculating Body Mass Index.

BMI was calculated as weight in kilograms/(height in meter)2. The cut off points given by World Health Organization[7] for the BMI for 5 -19 years of age were used for assessing overweight and obesity. Body Mass Index > 2 SD above WHO growth standard median for the particular age and sex was considered obese and BMI > 1 SD above WHO growth standard median for that age and sex was considered as overweight.

Data were analyzed using Epi info. Prevalence of overweight and obesity is presented as percentage. Odds ratio and $95 \%$ confidence interval was calculated for each categorical risk factor. Multiple logistic regression analysis was done with overweight and obesity together as dependent variable and age, sex, religion, type of family, parent's education \& occupation, type of diet, daily caloric intake, TV/video screen time, physical activity and duration of sleep as independent variables. $P<0.05$ was considered as statistically significant.

\section{Results}

Out of total 1690 study subjects aged 6-15 years, 980 [57.99\%] were boys and 710 [42.01\%] were girls. Out of 980 boys, 137 [13.98\%] were found overweight and 84 [8.57\%] were obese. Out of total 710 girls, 116 [16.34\%] were found overweight and 36 [5.07\%] were obese. Overall, 253 [14.97\%] children were overweight and 120 [7.10\%] were obese. Therefore, the prevalence of overweight/obese was $22.07 \%$. 
On univariate analysis, the risk of overweight/obesity was significantly higher among children of 10-15years age group than 6-10years age group. The children of employed mothers than children of non-employed mothers had higher risk. It was observed that children having mixed type of diet and daily caloric intake > RDA had a higher risk for obesity.
Also it was noted that children who slept for $<8$ hours/ day had a higher risk than children who slept for $\geq 8$ hours /day. Also those children who watched TV/video/computer for $>2 \mathrm{hr} /$ day and children who spent $<1 \mathrm{hr} /$ day in physical activity had higher risk. (Table No. 1, 2)

Table No.1: Risk factors of Overweight/obesity (Socio-demographic)

\begin{tabular}{|c|c|c|c|c|c|}
\hline & Variable & Total No. (\%) & Overweight/obesity No. (\%) & OR $(95 \% \mathrm{CI})$ & $P$ value \\
\hline Overall & & $1690[100]$ & $373[22.07]$ & - & - \\
\hline \multirow[t]{2}{*}{ 1\} Age } & $10: 01-15: 00$ & 945 [55.92] & 253 [26.77] & \multirow[t]{2}{*}{$1.904[1.494-2.427]$} & \multirow[t]{2}{*}{$<0.05$} \\
\hline & $6: 01-10: 00$ & $745[44.08]$ & $120[16.11]$ & & \\
\hline \multirow[t]{2}{*}{ 2\} Gender } & Male & 980 [57.99] & $221[22.55]$ & \multirow[t]{2}{*}{$1.069[0.8461-1.350]$} & \multirow[t]{2}{*}{0.59} \\
\hline & Female & $710[42.01]$ & $152[21.41]$ & & \\
\hline \multirow[t]{2}{*}{ 3\} Religion } & Hindu & $1390[82.25]$ & $308[22.16]$ & \multirow[t]{2}{*}{$1.029[0.7605-1.393]$} & \multirow[t]{2}{*}{0.87} \\
\hline & Others & $300[17.75]$ & 65 [21.67] & & \\
\hline \multirow[t]{2}{*}{ 4\} Type of Family } & Nuclear & $863[51.07]$ & $193[22.36]$ & \multirow[t]{2}{*}{$1.035[0.8226-1.303]$} & \multirow[t]{2}{*}{0.76} \\
\hline & Non- nuclear & 827 [48.93] & $180[21.77]$ & & \\
\hline \multirow[t]{2}{*}{ 5\} Father's education } & $\leq 12$ th Std & $214[12.66]$ & $47[21.96]$ & \multirow[t]{2}{*}{$0.9928[0.7022-1.404]$} & \multirow[t]{2}{*}{1.00} \\
\hline & $>12$ th Std & $1476[87.34]$ & $326[22.09]$ & & \\
\hline \multirow[t]{2}{*}{ 6\} Father's Occupation } & Professional \& Managerial & $1011[59.82]$ & $225[22.26]$ & \multirow[t]{2}{*}{$1.027[0.8120-1.299]$} & \multirow[t]{2}{*}{0.85} \\
\hline & Skilled Manual Worker \& Clerical & $679[40.18]$ & $148[21.80]$ & & \\
\hline \multirow[t]{2}{*}{ 7\} Mother's education } & $\leq 12$ th Std & $368[21.78]$ & 71 [19.29] & \multirow[t]{2}{*}{$0.8074[0.6074-1.078]$} & \multirow[t]{2}{*}{0.15} \\
\hline & $>12$ th Std & $1322[78.22]$ & $302[22.84]$ & & \\
\hline \multirow[t]{2}{*}{ 8\} Mother's Occupation } & Employed & 585 [34.62] & $163[27.86]$ & \multirow[t]{2}{*}{$1.646[1.301-2.083]$} & \multirow[t]{2}{*}{$<0.05$} \\
\hline & Not employed & 1105 [65.38] & 210 [19.00] & & \\
\hline
\end{tabular}

Table No. 2: Risk factors of Overweight/obesity (Life-style related)

\begin{tabular}{|c|c|c|c|c|}
\hline Variable & Total No. $(\%)$ & Overweight/obesity No. (\%) & OR $(95 \% \mathrm{CI})$ & $P$ value \\
\hline \multicolumn{5}{|c|}{ 1\} Type of Diet } \\
\hline Mixed & $914[54.08]$ & 228 [24.95] & \multirow[t]{2}{*}{$1.446[1.144-1.829]$} & \multirow[t]{2}{*}{0.002} \\
\hline Veg & 776 [45.92] & 145 [18.69] & & \\
\hline \multicolumn{5}{|c|}{ 2\} Daily Caloric Intake } \\
\hline$>$ RDA & $653[38.64]$ & $193[29.56]$ & \multirow[t]{2}{*}{$1.998[1.583-2.521]$} & \multirow[t]{2}{*}{$<0.05$} \\
\hline$\leq \mathrm{RDA}$ & $1037[61.36]$ & $180[17.36]$ & & \\
\hline \multicolumn{5}{|c|}{ 3\} Duration of sleep } \\
\hline$<8 \mathrm{hr} /$ day & $1152[68.17]$ & $320[27.78]$ & \multirow[t]{2}{*}{$3.520[2.577-4.806]$} & \multirow[t]{2}{*}{$<0.05$} \\
\hline$\geq 8 \mathrm{hr} /$ day & $538[31.83]$ & 53 [9.85] & & \\
\hline \multicolumn{5}{|c|}{ 4\} TV/Video Screen time } \\
\hline$>2 \mathrm{hr} /$ day & $933[55.21]$ & $250[26.80]$ & \multirow[t]{2}{*}{$1.887[1.482-2.402]$} & \multirow[t]{2}{*}{$<0.05$} \\
\hline$\leq 2 \mathrm{hr} /$ day & 757 [44.79] & $123[16.25]$ & & \\
\hline \multicolumn{5}{|c|}{ 5\} Physical Activity } \\
\hline$<1 \mathrm{hr} /$ day & 705 [41.72] & $201[28.51]$ & \multirow[t]{2}{*}{$1.885[1.495-2.377]$} & \multirow[t]{2}{*}{$<0.05$} \\
\hline$\geq 1 \mathrm{hr} /$ day & 985 [58.28] & 172 [17.46] & & \\
\hline
\end{tabular}


Multiple logistic regression was applied to determine the significant correlates of overweight/obesity in the study population. The final model (Table 3) showed that Employed mother, mixed diet, daily caloric intake $>$ RDA, Sleep at night $<8 \mathrm{hr} /$ day, TV/Video/ Computer Screen time $\geq 2 \mathrm{hr} /$ day and physical activity $<1 \mathrm{hr} /$ day were significantly associated with overweight/obesity among the study population.

Table No. 3: Determinants of overweight: Final model - Multivariate logistic regression

\begin{tabular}{|c|c|c|c|}
\hline Variable & $\begin{array}{l}\text { Odds } \\
\text { ratio }\end{array}$ & $95 \% \mathrm{CI}$ & value \\
\hline 1\} Employed mothers & 1.713 & $\begin{array}{l}1.328- \\
2.210\end{array}$ & $<0.05$ \\
\hline 2\} Mixed diet & 1.693 & $\begin{array}{l}1.300- \\
2.205\end{array}$ & $<0.05$ \\
\hline 3\} Daily caloric intake $>$ RDA & 1.991 & $\begin{array}{l}1.554- \\
2.550\end{array}$ & $<0.05$ \\
\hline 4\} Sleep at night $<8 \mathrm{hr} /$ day & 2.588 & $\begin{array}{l}1.786- \\
3.750\end{array}$ & $<0.05$ \\
\hline $\begin{array}{l}\text { 5\} TV/ Video, computer screen time } \geq 2 \\
\mathrm{hr} / \text { day }\end{array}$ & 2.098 & $\begin{array}{l}1.614- \\
2.728\end{array}$ & $<0.05$ \\
\hline 6\} Physical activity $<1 \mathrm{hr} /$ day & 1.527 & $\begin{array}{l}1.171- \\
1.992\end{array}$ & 0.002 \\
\hline
\end{tabular}

\section{Discussion}

Evaluation of obesity in children is important as it provides an opportunity to identify the problem and prevent disease progression in to adulthood. In the present study 253 [14.97\%] were found overweight and $120 \quad[7.10 \%]$ were obese while overweight/obese were 373 [22.07\%]. Similar findings were reported by other studies $[8,9,10$, $11]$.

Mozaffari $\mathrm{H}$ et al [12] found that BMI was directly and significantly correlated with increasing age and Thakre SB et al[10] showed that the risk of overweight/obesity was significantly higher to the children of age group $\geq 10$ years. The results of the above mentioned studies were similar to results found in present study.

However, Bodhare TN et al [9] found that increasing age was not significantly associated with obesity. The prevalence of obesity was more in adolescent age group than the child group in the present study population. This may be associated with increase in adipose tissue and overall weight gain during the pubertal growth spurt [13].
In our study, there was slight preponderance of males in prevalence of overweight/obesity showing no significant difference of gender in development of obesity. Similar results were found in study by Bodhare TN et al [9] and Bharati DR et al [1].

Present study finding was consistent with the findings of the studies by Keertan Kumar $M$ et al[14], Bodhare TN et al[9], Bharati DR et al[1] who found no significant difference of type of family in development of overweight/obesity. Thakre SB et al [10], Jain $S$ et al[15] and Mozaffari $H$. et al[12] found no statistical significance of obesity in relation to parents' education. This finding was similar to our study finding. However Mozaffari $\mathrm{H}$ et al [12] found a significant and inverse correlation between maternal education and occurrence of overweight/obesity in children.

Bharati DR et al [1] found that the risk of overweight/obesity was significantly higher among children of working mothers, similar to the present study. This was probably due to tendency of working mothers to resort on excessive use of convenience and processed foods, because it is easier to put together a meal at the end of the day. However, Thakre SB et al [10] observed no statistically significant difference in obese and non-obese group in regards of occupation of the mother.

We found that students taking mixed diet have significantly higher risk of development of obesity than students taking vegetarian diet. Similar findings by Thakre SB et al [10] and Iyer Uma et al [16] were reported in their study. However Bharati DR et al[1] found that type of diet was not a significant risk factor for overweight/obesity. Thakre SB et al [10] found that risk of overweight/obesity was significantly higher among children in whom the calorie intake was more than RDA. Iyer Uma et al [16] found that mean calorie intake was higher in obese and overweight children as compared to normal children. The findings of these studies were consistent with the present study finding.

Present study found that risk of obesity was significantly more in children who slept for $<8$ hours than children who slept for $\geq 8$ hours. Shaikh Wasim $A$ et al [17] and Kurian $R$ et al[18] had similar finding in their study. It was possible that greater sleep duration leads to a higher likelihood that the child will be more physically active, which leads to a lower risk for overweight. Alternatively, more physical activity may both increase sleep and reduce weight gain. 
Jain $S$ et al [15], Mane AB [11], Bodhare TN et al [9], and Mozaffari $\mathrm{H}$ et al [12] found that duration of TV/computer watching was significantly higher in overweight/obese children. This was similar to our study finding. However, Keertan Kumar M et al [14] and Bharati DR et al [1] found that there was no significant association between duration of TV/ computer watching and obesity. Bharati DR et al [1], Jain $S$ et al [15], Bodhare TN et al [9] and Mozaffari $\mathrm{H}$ et al [12] found that reduced physical and sports activity was significantly associated with obesity. This finding was similar to our study finding.

Strength of this study is that use of a new growth reference recommended by WHO for school aged children [5-19 years old].

\section{Conclusion}

In the present study, the important determinants of the overweight/obesity were employed mothers, mixed diet, daily caloric intake $>$ RDA, sleep at night $<8 \mathrm{hr} /$ day, TV/video/computer screen time $\geq 2$ $\mathrm{hr} /$ day and physical activity $<1 \mathrm{hr} /$ day. All these factors were related to lifestyle of the children \& modifiable. This implies the importance of lifestyle related factors in the predisposition of an individual to overweight/obesity. Therefore there is a need to educate the community about healthier eating habits and an active life style in preventing obesity for the health of future generation.

\section{Reference}

01. Bharati DR, Deshmukh PR, Garg BS. Correlates of overweight \& obesity among school going children of Wardha city, Central India. Indian J Med Res. 2008;127(6)539-43.

[Crossref]

02. Obesity- preventing and managing the global epidemic. Report of a WHO consultation. World Health Organ Tech Rep Ser. 2000;894;i-xii, 1253.

[Crossref]

03. Sharma S. Obesity - A Global Menace. Indian Journal of Maternal and Child Health. 2010;12(2)1-8.

[Crossref]

04. Ramachandran A, Snehalatha C. Prevention of childhood obesity should be an integral part of prevention of non communicable diseases. Indian J Med Res. 2008;127(6)514-5.
05. Agarwal RK. Childhood obesity- emerging challenge. Indian Pediatr. 2008;45(6)443-4.

[Crossref]

06. Greydanus DE, Bhave S. Obesity and adolescents- time for increased physical activity!. Indian Pediatr. 2004;41(6)545-50.

[Crossref]

07. World Health Organization. World Health Organization Child Growth Standards.

Available on: [Article] [Crossref]

08. Sharma A, Sharma K, Mathur KP. Growth pattern and prevalence of obesity in affluent school children of Delhi. Public Health Nutr. 2007; 10(5)485-91.

[Crossref]

09. Trupti NB, Samir DB, Valsangkar S, Budaraju S. Predictors of Childhood Overweight and Obesity in Children aged 5-14 years in an Urban area of Karimnagar district, Andhra Pradesh. Indian Journal Of Maternal And Child Health. 2010;12(4)1-9.

[Crossref]

10. Thakre SB, Mohane SP, Ughade SM, Thakre SS, Morey SS, Humne AY. Correlates of Overweight and Obesity Among Urban School Going Children of Nagpur City. Journal of Clinical and Diagnostic Research. 2011;5;1593-7. [Crossref]

11. Mane AB, Rao EV, Gupta S. Obesity and its correlates among affluent school going adolescents in urban area. Indian Journal of Maternal and Child Health. 2011;13(4)1-9. [Crossref]

12. Mozaffari $\mathrm{H}$, Nabaei B. Obesity and Related Risk Factors. Indian J Pediatr. 2007;74(3)265-7. [Crossref]

13. Kapil $U$, Singh $P$, Pathak $P$, Dwivedi SN, Bhasin $S$. Prevalence of obesity in affluent adolescent school children in Delhi. Indian Pediatr. 2002;39(5)449-52.

[Crossref]

14. Kumar MK, Prashanth K, Baby KE, Rao KR, Kumarkrishna B, Hegde $K$, et al. Prevalence Of Obesity Among High School Children In Daksh in a Kannada And Udupi Districts. Nitte University Journal of Health Science. 2011; $1 ; 16-20$.

[Crossref] 
15. Jain S, Pant B, Chopra H, Tiwari R. Obesity Among Adolescents of Affluent Public Schools in Meerut. Indian J Public Health. 2010;54(3)15860.

doi: $10.4103 / 0019-557 X .75740$ [Crossref]

16. Iyer U, Elayath $\mathrm{N}$, Akolkar A. Magnitude and Determinants of Overweight and Obesity in 6-12 year old school children of Vadodara City. Curr Pediatric Research. 2011;11(2)105-9.

[Crossref]
17. Shaikh WA, Patel M, Singh SK. Sleep Deprivation Predisposes Gujarati Indian Adolescents to Obesity. Indian J Community Med. 2009;34(3)192-4.

doi: $10.4103 / 0970-0218.55282$ [Crossref]

18. Kuriyan R, Bhat $S$, Thomas $T$, Vaz M, Kurpad AV. Television Viewing and Sleep are associated with Overweight among urban and semi-urban South Indian children. Nutr J. $2007 ; 20 ; 6 ; 25$.

[Crossref] 